\title{
Oxygen-independent Intracellular and Oxygen-dependent Extracellular Killing of Escherichia coli S15 by Human Polymorphonuclear Leukocytes
}

Jerrold Weiss, Linda Kao, Michael Victor, and Peter Elsbach

Department of Medicine, New York University School of Medicine, New York 10016

\begin{abstract}
Effective killing of bacteria by polymorphonuclear leukocytes (PMN) is generally assumed to require intracellular sequestration and, depending on the bacterial species, can be both $\mathrm{O}_{2^{-}}$ dependent or $\mathrm{O}_{2}$-independent. Killing of several strains of Salmonella typhimurium and Escherichia coli by rabbit PMN does not require $\mathrm{O}_{2}$ and is apparently due to a granuleassociated bactericidal/permeability-increasing protein (BPI) present in rabbit and human PMN. In this study we examined the $\mathrm{O}_{2}$ dependence of the killing of $E$. coli (S15) by human $P M N$. Ingested and noningested $E$. coli were separated by centrifugation after incubation with $P M N$ in room air or under $N_{2}$. In the presence of heat-treated serum $\sim 50 \%$ of $E$. coli (10 bacteria/PMN) were taken up by PMN and rapidly (5-15 min) killed both in room air and under $N_{2}$. The remaining extracellular bacteria $(\sim 50 \%)$ were killed during 30-60 min of incubation in room air but not under $N_{2}$. When uptake of $E$. coli by PMN was increased to $\sim \mathbf{8 0 \%}$ by the use of C6depleted serum (retaining heat-labile opsonins), bacterial survival under $\mathrm{N}_{2}$ was reduced from $54 \pm 7.6 \%$ to $13 \pm 5.5 \%$. PMN from a patient with chronic granulomatous disease killed PMN-associated but not extracellular $E$. coli. BPI was detected, by indirect immunofluorescence, on the surface of PMNassociated $E$. coli within $5 \mathrm{~min}$ of incubation of $E$. coli with PMN both in room air and under $\mathbf{N}_{2}$. In contrast, at no time was BPI detected on the surface of extracellular $E$. coli, indicating that the non-PMN-associated $E$. coli had not been previously ingested. Thus, killing of ingested $E$. coli S15 by human as well as rabbit PMN does not require $\mathrm{O}_{2}$ and appears to be BPI-mediated. However, when ingestion is limited, extracellular bacteria can also be killed but principally by $\mathrm{O}_{2}$ dependent mechanisms.
\end{abstract}

\section{Introduction}

Polymorphonuclear leukocytes (PMN) kill bacteria by $\mathrm{O}_{2}$ dependent and $\mathrm{O}_{2}$-independent mechanisms $(1,2)$. Although substances contributing to both oxidative and nonoxidative modes of killing are released outside the phagocyte as well as

A preliminary report of this work was presented at the annual meeting of the American Society for Clinical Investigation, Washington, DC, 4-7 May 1984, and was published in abstract form, 1984. Clin. Res. 32:A517.

Received for publication 13 August 1984 and in revised form 15 February 1985.

J. Clin. Invest.

(c) The American Society for Clinical Investigation, Inc.

0021-9738/85/07/0206/07 \$1.00

Volume 76 , July $1985,206-212$ into the phagocytic vacuole (3), evidence of substantial extracellular killing of bacteria under normal circumstances is lacking. Hence, effective bacterial killing by PMN is generally presumed to require intracellular sequestration of bacteria (4). We now provide evidence that human PMN do kill extracellular Escherichia coli (S15). Extracellular killing of this $E$. coli strain is only effective in the presence of $\mathrm{O}_{2}$, in contrast to killing of ingested $E$. coli, which does not require $\mathrm{O}_{2}$.

\section{Methods}

$P M N$. Heparinized venous blood was obtained after informed consent from healthy volunteers and from a patient with a previously diagnosed, $X$-linked form of chronic granulomatous disease (CGD)' (5). Antibiotic prophylaxis (160 mg of trimethoprim and $800 \mathrm{mg}$ of sulfamethoxazole daily) of the patient was interrupted $60 \mathrm{~h}$ before bleeding. PMN were isolated by sedimentation in Ficoll-Paque and dextran T-500 (Pharmacia Fine Chemicals, Piscataway, NJ) (6). Wright stains of blood smears showed that $>95 \%$ of cells were PMN, $\sim 95 \%$ of which were neutrophils and 5\% eosinophils. The cells were washed twice with Hanks' balanced salt solution (HBSS; M.A. Bioproducts, Walkersville, MD) before resuspension in $\mathrm{HBSS}$ containing $20 \mathrm{mM}$ Tris- $\mathrm{HCl}, \mathrm{pH} 7.5$, to a concentration of $4 \times 10^{7} \mathrm{PMN} / \mathrm{ml}$.

Bacteria. E. coli S15, a K12 strain (Leu--Thr'--Thi $\left.{ }^{-}-\mathrm{Lac}^{-}-\mathrm{Mal}^{-}\right)$, was kindly provided by Prof. S. Nojima, Faculty of Pharmaceutical Sciences, University of Tokyo.

Growth and labeling of bacteria. The bacteria were grown in a triethanolamine-buffered ( $\mathrm{pH}$ 7.75-7.9) minimal salts medium (7). Stationary-phase overnight cultures were transferred to fresh medium (diluted 1:10) supplemented with either L-amino acids mixture $\left[{ }^{14} \mathrm{C}\right.$ (uniform) $], 0.5 \mu \mathrm{Ci} / \mathrm{ml} ;>250 \mathrm{Ci} / \mathrm{mol}$; or $\left[2-{ }^{14} \mathrm{C}\right]$ thymidine, 0.5 $\mu \mathrm{Ci} / \mathrm{ml} ; 62 \mathrm{Ci} / \mathrm{mol}$ (New England Nuclear, Boston, MA) plus cold uridine $(2 \mathrm{mM})$ to prelabeled bacterial proteins or DNA, respectively. After growth to midlogarithmic phase $\left(2.5-4 \mathrm{~h}\right.$ at $37^{\circ} \mathrm{C} ; 0.5-1 \times 10^{9}$ bacteria/ml, determined by measuring absorbance at $550 \mathrm{~nm}$ ), the bacteria were harvested by centrifugation at $6,000 \mathrm{~g}$ for $10 \mathrm{~min}$, resuspended in growth medium without radioactive precursors, and incubated for $30 \mathrm{~min}$ at $37^{\circ} \mathrm{C}$ to chase residual precursors into macromolecules. The bacteria were then pelleted again and resuspended in sterile physiologic saline to $5 \times 10^{8} / \mathrm{ml}$. Radiolabeled $E$. coli contained $>1,500 \mathrm{cpm} / 10^{7}$ bacteria, $>95 \%$ of which were precipitable in cold $5 \%$ trichloroacetic acid.

Sera. Sera collected from many normal human donors were pooled. Heat-treated serum was prepared by incubation of serum at $56^{\circ} \mathrm{C}$ for $45 \mathrm{~min}$ before use. C6-depleted serum was prepared by immunoaffinity chromatography of normal (untreated) serum on Affi-Gel 10 (Bio-Rad Laboratories, Richmond, CA) containing covalently coupled goat (antihuman C6) IgG (Calbiochem-Behring Corp., San Diego, CA), prepared according to the instructions of the manufacturer. Recovery of unbound human serum protein ( $>95 \%$ ) was measured by the modified Coomassie blue assay (8). Depletion of C6 was monitored by double immunodif-

1. Abbreviations used in this paper: BPI, bactericidal/permeabilityincreasing protein; CGD, chronic granulomatous disease; PBSA, phosphate-buffered saline containing $0.2 \%$ bovine serum albumin. 
fusion of unbound human serum protein against goat (anti-human C6) antibody (9).

Serum was collected from a New Zealand White rabbit before and after immunization with purified human bactericidal/permeabilityincreasing protein (BPI) (10) to provide preimmune and immune (antiBPI) sera. To deplete immune sera of anti-BPI antibodies, antiserum was incubated with purified BPI $(2 \mathrm{~h}$ at room temperature, then $24 \mathrm{~h}$ at $4^{\circ} \mathrm{C}$ ) and spun $(10,000 \mathrm{~g}$ for $10 \mathrm{~min})$ to remove immune complexes. Antibody titer was determined by double immunodiffusion of serum against BPI (9). Anti-BPI serum produced a single-fused precipitin line against purified BPI and crude PMN extracts.

Incubation mixtures. Typical incubation mixtures contained 0.25 $\mathrm{ml}$ of $\mathrm{HBSS} / 20 \mathrm{mM}$ Tris- $\mathrm{HCl}(\mathrm{pH} 7.5) \pm \mathrm{PMN}\left(10^{7}\right), 0.05 \mathrm{ml}$ of heattreated pooled human serum (or saline), and $0.20 \mathrm{ml}$ of $E$. coli $\left(10^{8}\right)$ in 10-ml siliconized Vacutainer tubes (no additive; Beckton, Dickinson \& Co., Rutherford, NJ).

Incubation conditions: $\mathrm{O}_{2}$ depletion. Before mixing PMN and $E$. coli, individual samples containing PMN and serum and stock bacterial suspensions were equilibrated at room temperature in room air or under $\mathrm{N}_{2}$ to create aerobic or $\mathrm{O}_{2}$-depleted conditions. $\mathrm{N}_{2}$ (prepurified; Ohio Medical Products, Madison, WI) flushing was accomplished via 21- (inlet) and 18- (outlet) gauge needles inserted through the rubber stopper that seals these tubes. Flushing was carried out for $20-30 \mathrm{~min}$ (longer flushing, up to $60 \mathrm{~min}$, did not alter the results). PMN suspensions were periodically shaken by hand to reduce cell clumping. The bacteria were added to tubes containing PMN via syringe. $\mathrm{N}_{2}$ flushing was continued for $5 \mathrm{~min}$ before removing the needles and sealing the tubes. Incubations were carried out in a rotating, $(\sim 100$ rpm) waterbath at $37^{\circ} \mathrm{C}$ and stopped by placing the tubes in ice and diluting the suspensions fourfold with ice-cold sterile saline containing sodium heparin $(50 \mathrm{U} / \mathrm{ml})$ to block further phagocytosis and killing (11). The bacteria did not multiply during $60 \mathrm{~min}$ of incubation in the absence of PMN $(100 \pm 4.3 \%$ and $95 \pm 2.5 \%$ of 0 min viability in the absence and presence of serum, respectively). $\mathrm{N}_{2}$-flushed PMN generated almost no respiratory burst ( $<3 \%$ of normal), measured either by hexose monophosphate shunt activity or by $\mathrm{O}_{2}^{-}$production (12).

Measurement of uptake of E. coli by PMN. After cooling and dilution of the cell suspensions, $1 \mathrm{ml}$ was transferred by syringe to a second $\mathrm{N}_{2}$-flushed tube for measurement of bacterial viability in whole cell suspensions (see below). $1 \mathrm{ml}$ of $1.0 \mathrm{M}$ sucrose was injected beneath the remaining $1 \mathrm{ml}$ of cell suspension and free and PMNassociated $E$. coli were separated by centrifugation at $100 \mathrm{~g}$ for $10 \mathrm{~min}$ in a swinging bucket rotor. The PMN sedimented through the sucrose layer. The supernatant $(\sim 2 \mathrm{ml})$ was carefully removed $(<100 \mu l$ remained) and the PMN pellet was resuspended in saline-heparin to the volume of the supernatant fraction. Bacterial radioactivity in the resuspended PMN pellet ("PMN associated") and in the supernatant fraction ("extracellular") were measured by conventional liquid scintillation counting procedures (11). Supernatant $E$. coli were also enumerated by light microscopy using a Petroff-Hauser bacterial counting chamber. Bacterial uptake by PMN was measured as: $(a)$ percentage of total recovered bacterial radioactivity present in the resuspended PMN pellet; and $(b)$ percent reduction in the number of $E$. coli in the supernatant. The distribution of bacterial radioactivity was comparable using ${ }^{14} \mathrm{C}$-amino acid or $\left[{ }^{14} \mathrm{C}\right]$ thymidine-labeled $E$. coli and the supernatant radioactivity corresponded closely $( \pm 10 \%)$ to the number of $E$. coli enumerated under the microscope. Total recovery of bacterial radioactivity was $96 \pm 3.1 \%$; $96 \pm 0.7 \%$ of $E$. coli were recovered in the supernatant fraction in the absence of PMN $(n=8)$.

To determine the properties of uningested bacteria and of the cellfree incubation mixture, cell suspensions were centrifuged at $100 \mathrm{~g}$ for $10 \mathrm{~min}$.

Measurement of bacterial viability. To measure bacterial viability (i.e., colony-forming ability), samples were serially diluted in sterile saline and plated on nutrient agar. Samples of whole cell suspensions were taken both before and after sonication of the suspensions $(40 \mathrm{~W}$ for $15 \mathrm{~s}$ at $0-4^{\circ} \mathrm{C}$; Sonifier Cell Disrupter, Heat Systems-Ultrasonics, Inc., Farmingdale, NY) to detèrmine extracellular and total (extraand intracellular) bacterial viability, respectively. Sonication under the indicated conditions does not affect bacterial viability, but lyses PMN, releasing intracellular bacteria. The viability of PMN-associated and of extracellular $E$. coli was measured only after sonication. The number of colony-forming units on the plates was determined after incubation at $37^{\circ} \mathrm{C}$ overnight.

Immunofluorescence. Samples (5-10 $\mu \mathrm{l})$ of sonicated whole cell suspensions, resuspended PMN pellets and supernatants, and $E$. coli preincubated \pm BPI were dried on precleaned microscope slides and fixed $\left(1 \mathrm{~min}\right.$ at $\left.4^{\circ} \mathrm{C}\right)$ in buffered formalin acetone (13). The fixed smears were soaked for $15 \mathrm{~min}$ in Dulbecco's phosphate-buffered saline (PBS), and rinsed with PBS supplemented with $0.2 \%$ bovine serum albumin (PBSA). Smears were overlaid for $10 \mathrm{~min}$ in a moist chamber at room temperature with $10 \%$ heat-treated pooled human serum, to occupy nonspecific binding sites, and rinsed with PBSA Next, smears were overlaid with either $0.5 \%$ rabbit anti-BPI, preimmune, or depleted serum for $30 \mathrm{~min}$, washed three times for $30 \mathrm{~min}$ with PBS, rinsed with PBSA, and finally overlaid with $1 \%$ rhodaminelabeled swine (anti-rabbit Ig) Ig (Accurate Chemical \& Scientific Corp., Westbury, NY) for $30 \mathrm{~min}$. All sera were diluted in PBSA. Excess rhodamine-labeled Ig was removed in three washes $(30 \mathrm{~min})$ with PBS and the smears were covered with glycerol:PBS $(9: 1, \mathrm{vol} / \mathrm{vol})$ and a coverslip and examined under oil using a Leitz Orthoplan fluorescent microscope (E. Leitz, Inc., Rockleigh, NY). Immunofluorescent staining of $E$. coli pretreated with purified BPI was not reduced either by sonication or by subsequent addition of heparin \pm heat-treated human serum. Heparin prevents attachment of unbound BPI to E. coli (14); $E$. coli exposed to BPI in the presence of heparin $(50 \mathrm{U} / \mathrm{ml})$ were not stained. Photographs were taken with Kodak Tri-X pan (ASA 400) film at approximately $\times 1,000$ magnification. The micrographs shown in Fig. 2 were further enlarged 3-4X during photography.

Radioimmunoassay. E. coli preincubated $\pm \mathrm{BPI}$ or recovered in supernatants of PMN suspensions were sedimented by centrifugation at $10,000 \mathrm{~g}$ for $10 \mathrm{~min}$ to remove unbound protein. The bacteria were resuspended in isotonic saline containing $1 \%$ Triton $\mathrm{X}-100,1 \%$ sodium deoxycholate and $1 \mathrm{mM}$ phenylmethyl sulfonyl fluoride $\left(2 \times 10^{8} / \mathrm{ml}\right)$, sonicated (as above), and incubated for $60 \mathrm{~min}$ at room temperature. Aliquots $(20 \mu \mathrm{l})$ of the bacterial extracts were dried on $1.3 \mathrm{~cm}^{2}$ strips of nitrocellulose paper (Bio-Rad Laboratories). The strips were then soaked in Tris ( $10 \mathrm{mM}$; pH 7.5)-buffered saline, containing 3\% bovine serum albumin to saturate protein-binding sites before incubation with $1 \%$ rabbit (anti-BPI or preimmune) serum and, after several washes with Tris-buffered saline, with ${ }^{125} \mathrm{I}$-goat (anti-rabbit $\left.\mathrm{IgG}\right) \mathrm{F}(\mathrm{ab})_{2}$ (2 $\times 10^{5} \mathrm{cpm}$ ) (New England Nuclear) and unlabeled goat (anti-rabbit IgG) IgG (10 $\mu \mathrm{g} / 1.5 \mathrm{ml}$ ) (Miles Scientific, Naperville, IL). All antibody preparations were diluted in Tris-buffered saline supplemented with $3 \%$ albumin, $0.5 \%$ nonidet $\mathrm{P}-40,5 \mathrm{mM}$ EDTA, and $0.05 \% \mathrm{NaN}_{3}$. The nitrocellulose strips were again washed with Tris-buffered saline before counting in a gamma counter. Extracts of $E$. coli, killed by BPI, bound 4-5 $\times 10^{3} \mathrm{cpm}$ (above background) when treated with anti-BPI rabbit serum and $<30 \mathrm{cpm}$ when treated with preimmune rabbit serum.

\section{Results}

Reduced killing of E. coli $\mathrm{S} 15$ by human PMN during $\mathrm{O}_{2}$ deprivation. Killing of Salmonella typhimurium and E. coli by rabbit PMN is equally effective in room air and under $\mathrm{N}_{2}(12$; Elsbach, P., L. Kao, M. Victor, and J. Weiss, unpublished observations). However, killing of $E$. coli $\mathrm{S} 15$ by human PMN was markedly reduced under $\mathrm{N}_{2}$ (Table I). Human PMN, unlike rabbit PMN $(12,15)$, are unable to kill rough strains of gram-negative bacteria such as $E$. coli $\mathrm{S} 15$ in the absence of serum (data not shown). In the presence of 10\% heat-treated 
Table I. Killing of E. coli S15 by Human

PMN Under Room Air and $\mathrm{N}_{2}$

\begin{tabular}{|c|c|c|c|c|}
\hline \multirow{3}{*}{$\begin{array}{l}\text { Incubation } \\
\text { time }\end{array}$} & \multicolumn{4}{|c|}{ Bacterial viability } \\
\hline & \multicolumn{2}{|l|}{ Room air } & \multicolumn{2}{|l|}{ Nitrogen } \\
\hline & -Sonic. & +Sonic. & -Sonic. & + Sonic. \\
\hline $\min$ & \multicolumn{4}{|c|}{ \% of E. coli incubated without $P M N$} \\
\hline 15 & NT‡ & $49 \pm 3.2$ & NT & 63 \\
\hline 30 & $22 \pm 4.2$ & $23 \pm 3.4$ & $61 \pm 8.9$ & $62 \pm 5.8$ \\
\hline 60 & $8 \pm 4.7$ & $10 \pm 2.1$ & $44 \pm 7: 7$ & $47 \pm 4.3$ \\
\hline
\end{tabular}

E. coli $\mathrm{S} 15 \pm \mathrm{PMN}(10 \mathrm{E}$. coli/PMN) were incubated in the standard incubation mixture (containing $10 \%$ heat-treated serum) at $37^{\circ} \mathrm{C}$ for the indicated time under room air or $\mathrm{N}_{2}$. Bacterial viability was measured before and after sonication of cell suspensions as described in Methods. The values shown represent viability of $E$. coli incubated with PMN expressed as percent of viability of $E$. coli incubated without PMN and are the mean ( \pm SEM, where indicated) of results obtained in from 2 to 13 experiments. Viability of sonicated $E$. coli suspensions (no PMN) is $99 \pm 5.2 \%$ of unsonicated bacterial suspensions. Sonic., sonication; NT, not tested.

serum, the viability of $E$. coli incubated with human PMN in room air decreased progressively, falling to $<10 \%$ after $60 \mathrm{~min}$ (Table I). Under $\mathrm{N}_{2}$, most killing took place within the first $15 \mathrm{~min}$ and nearly $50 \%$ of the added bacteria remained viable after $60 \mathrm{~min}$. After sonication to release ingested $E$. coli, the number of viable bacteria measured was nearly the same as before sonication indicating that there was no appreciable intracellular survival and, hence, that $E$. coli surviving under $\mathrm{N}_{2}$ were extracellular.

Evidence of $\mathrm{O}_{2}$-independent intracellular killing and $\mathrm{O}_{2}$ dependent extracellular killing. To assess more directly the location of live and dead $E$. coli after incubation with PMN, PMN-associated and extracellular radiolabeled $E$. coli were separated by low-speed centrifugation. Maximally, only about half of the added $E$. coli were recovered in the PMN pellet whether incubated in room air or under $\mathrm{N}_{2}$ (Fig. 1); this fraction was not increased by reducing the number of $E$. coli added per PMN (from 10 to 3 ) or by increasing the amount of serum added (up to $40 \%$ ). Most uptake occurred within the first 5-15 min and PMN-associated bacteria were efficiently killed in room air as well as under $\mathrm{N}_{2}$ (Fig. 1). After $5 \mathrm{~min}$ in room air, $>50 \%$ of $E$. coli recovered in the PMN pellet were nonviable and nearly all were dead after $30 \mathrm{~min}$. The rate and extent of killing of PMN-associated bacteria were only slightly less under $\mathbf{N}_{2}$ (Fig. 1).

In contrast, the viability of the remaining extracellular $E$. coli differed greatly in room air and under $\mathrm{N}_{2}$ (Fig. 1). Initially (5-15 min), most $E$. coli recovered in the extracellular medium of aerobic and $\mathrm{O}_{2}$-depleted cell suspensions were viable. After longer incubation in room air, nearly all $(84 \pm 4.5 \%)$ recovered extracellular bacteria were nonviable. However, after $60 \mathrm{~min}$ of incubation under $\mathrm{N}_{2}$, only a small fraction $(21 \pm 7.7 \%)$ of the extracellular $E$. coli were killed. Thus, reduced killing of $E$. coli $\mathrm{S} 15$ under $\mathrm{N}_{2}$ appears to be attributable to increased survival of extracellular but not of intracellular bacteria.

These findings suggest two mechanisms of killing of $E$. coli $\mathrm{S} 15$ by human PMN: $\mathrm{O}_{2}$-independent (i.e., $\mathrm{O}_{2}$ is not required)

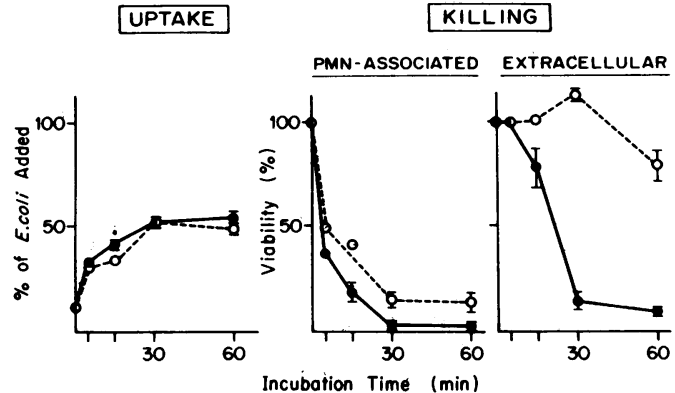

Figure 1. Intracellular and extracellular killing of $E$. coli $\mathrm{S} 15$ by PMN in room air or $\mathrm{N}_{2}$. E. coli and PMN (10 E. coli/PMN) were incubated for various periods in the standard incubation mixture (containing $10 \%$ heat-treated serum) at $37^{\circ} \mathrm{C}$ in room air (๑) or under $\mathrm{N}_{2}(0)$. PMN-associated and extracellular bacteria were separated by centrifugation (see Methods). Uptake of $E$. coli by PMN and the viability of PMN-associated and extracellular bacteria were measured as described under Methods. Bacterial uptake (measured by radioactive and/or microscopic counting; see Methods) is expressed as the percentage of added $E$. coli which is recovered in the PMN pellet. Bacterial viability is expressed as the percentage of bacteria recovered in each fraction which is viable. The results shown represent the mean ( \pm SEM, where indicated) of from two to seven experiments.

intracellular killing and $\mathrm{O}_{2}$-dependent extracellular killing. This conclusion is supported by results obtained in an experiment with PMN from a patient with CGD whose leukocytes cannot generate toxic $\mathrm{O}_{2}$ metabolites (1). As shown for $\mathrm{O}_{2}$ depleted normal PMN, CGD leukocytes killed nearly all PMNassociated but few extracellular $E$. coli (Table II). Overall killing of $E$. coli $\mathrm{S} 15$ by CGD leukocytes was only slightly less than by normal PMN apparently because a greater fraction of the bacteria were taken up by the patient's PMN (76\% vs. $55 \pm 2.7 \%(54 \%$ in this experiment $))$ and killed by $\mathrm{O}_{2}$-independent mechanisms. The patients' PMN did not kill Staphylo-

Table II. Normal Intracellular but Defective Extracellular Killing of E. coli S15 by CGD Leukocytes

\begin{tabular}{lllll}
\hline & & \multicolumn{2}{l}{ *Viability of E. coli in } \\
\cline { 3 - 5 } PMN (atmosphere) & Uptake & $\begin{array}{l}\text { Whole } \\
\text { suspension }\end{array}$ & $\begin{array}{l}\text { PMN } \\
\text { pellet }\end{array}$ & Supernatant \\
\hline & $\%$ & $\%$ & $\%$ & $\%$ \\
Normal (room air) & $55 \pm 3$ & $10 \pm 2$ & $4 \pm 1$ & $14 \pm 5$ \\
Normal (N $N_{2}$ ) & $48 \pm 3$ & $47 \pm 4$ & $14 \pm 4$ & $79 \pm 8$ \\
CGD (room air) & 76 & 17 & 3 & 71
\end{tabular}

$E$. coli $\mathrm{S} 15$ were incubated for $60 \mathrm{~min}$ at $37^{\circ} \mathrm{C}$ in the standard incubation mixture (containing 10\% heat-treated serum) $\pm \mathrm{PMN}$ under room air or $\mathrm{N}_{2}$. Bacterial uptake and viability were measured as described under Methods. The effects of CGD leukocytes that are shown represent the results obtained in a single experiment. The results (mean \pm SEM) shown for normal PMN (incubated either in room air or under $\mathrm{N}_{2}$ ) are shown for comparison and represent the data shown in Table I and Fig. 1 to which were added those of two controls included in this experiment.

* The numbers shown represent the percent of bacteria recovered after $60 \mathrm{~min}$ of incubation in whole suspension, PMN pellet, or supernatant (determined as described in Methods) that were viable. 
coccus aureus, a bacterial species that is not effectively killed by $\mathrm{O}_{2}$-independent bactericidal mechanisms $(1,12)$. This indicates that omission of antibiotics for $60 \mathrm{~h}$ before blood was withdrawn from the patient eliminates the effect of the antibiotics on the bactericidal potential of the PMN in vitro (16).

Granule-associated BPI is bound to the surface of PMNassociated, but not of extracellular, $E$. coli. To verify that extracellular $E$. coli represent noningested rather than previously ingested and extruded bacteria, we examined the bacteria after incubation with PMN to determine whether BPI, a granuleassociated protein, had attached to $E$. coli. BPI, in crude PMN fractions as well as in purified form, has a high affinity for $E$. coli $(12,17)$ and rapidly binds to the bacterial surface (18). However, $10 \%$ serum (added to suspensions with intact PMN) inhibits binding of BPI to $E$. coli (unpublished observations). Thus, transfer of BPI from PMN granules to the surface of $E$. coli S15 can only occur inside, not outside the PMN.

BPI binding to $E$. coli was readily seen by indirect immunofluorescence (Fig. 2). E. coli killed by either crude (granulerich) cell-free PMN fractions or by purified BPI show bright fluorescent staining after fixation and treatment with rabbit anti-BPI serum and rhodamine-labeled swine (anti-rabbit IgG) antibodies (Fig. 2, top left). No bacterial staining was seen when BPI-killed $E$. coli were treated with preimmune serum (Fig. 2, bottom left panel) or immune serum depleted of antiBPI antibodies, nor when either immune (Fig. 2, top right), preimmune (Fig. 2, bottom right) or depleted antisera were used to treat $E$. coli that had not been exposed to BPI. Thus bacterial fluorescence is specifically due to the reaction of antiBPI antibodies with BPI bound to $E$. coli.

$E$. coli recovered in the PMN pellet after aerobic or anaerobic incubation with intact PMN were also brightly fluorescent when treated with anti-BPI serum (Fig. 3, top center) but not when treated with preimmune serum (Fig. 3, bottom center). After $5 \mathrm{~min}$ of incubation, most PMN-associated bacteria were stained; after $15 \mathrm{~min}$, essentially all $E$. coli were fluorescent. In contrast, no extracellular $E$. coli were stained at any time (up to $60 \mathrm{~min}$ ) (Fig. 3, top right) nor was any bound BPI detectable on extracellular $E$. coli by radioimmunoassay (sensitivity limit: $<3 \%$ of lethal BPI dose). Whole suspensions of $E$. coli and PMN sonicated without prior incubation also showed little or no bacterial fluorescence (Fig. 3; top left). Therefore, the fluorescence of PMN-associated $E$. coli reflects the rapid binding of BPI to $E$. coli, which occurred within the intact neutrophil and not during the disruption of PMN by sonication. Hence the absence of detectable BPI on extracellular $E$. coli confirms that these bacteria were not ingested at any time and, in room air, were killed extracellularly.

Effects of serum on uptake and killing by PMN. When viable extracellular $E$. coli, recovered from $\mathrm{O}_{2}$-depleted $\mathrm{PMN}$ suspensions, were incubated with a fresh population of PMN, roughly $50 \%$ of the bacteria were again ingested indicating that the noningested bacteria were not intrinsically resistant to phagocytosis. To determine whether limited ingestion was due to weak opsonizing activity of heat-treated serum, we prepared C6-depleted serum, which retains the opsonic but not the bactericidal activity of the heat-labile complement system (19). Indeed, when heat-treated serum was replaced by C6-depleted serum, bacterial uptake by PMN increased to nearly $80 \%$ (Table III). Again, nearly all PMN-associated $E$. coli were killed in $\mathrm{O}_{2}$-depleted as well as normally aerated cell suspensions. Consequently, overall bacterial killing under $\mathrm{N}_{2}$ was substantially greater when C6-depleted, rather than heat-treated, serum was used and was only slightly less than bacterial killing in room air (Table III). The somewhat greater killing under $\mathrm{N}_{2}$ of extracellular bacteria, when C6-depleted serum was used,

\section{+ BPI}

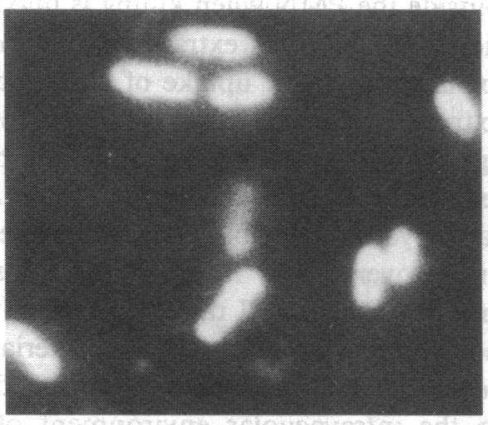

\section{ANT I -BPI} serum

\section{PREIMMUNE serum}

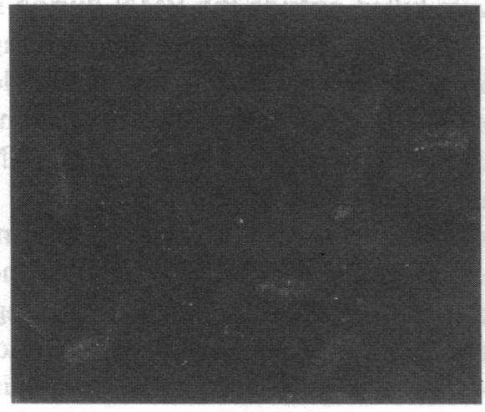

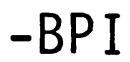
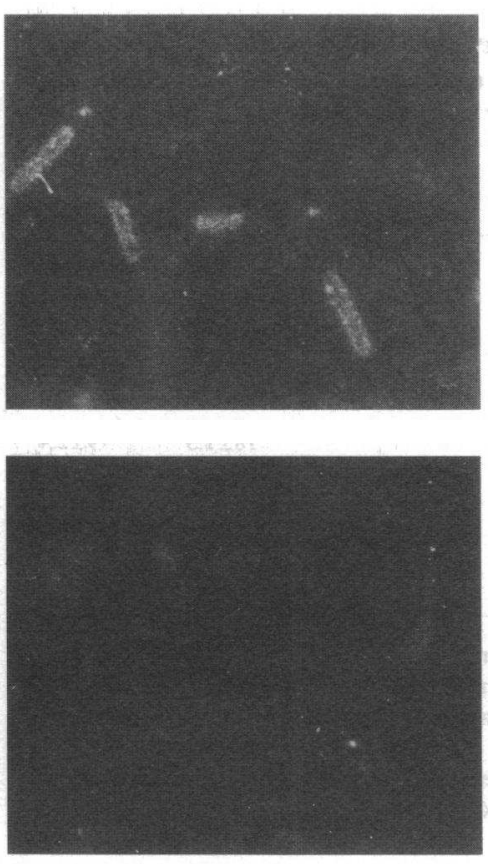

Figure 2. Detection of BPI binding to $E$. coli $\mathrm{S} 15$ by indirect immunofluorescence. E. coli $\left(3 \times 10^{7} / \mathrm{ml}\right)$ were incubated for $5 \mathrm{~min}$ in the presence (left) or absence (right) of BPI $(3 \mu \mathrm{g} / \mathrm{ml})$. Indirect immunofluorescent staining of $E$. coli was carried out as described under Methods. Bacteria shown in upper and lower panels were treated with rabbit anti-BPI and preimmune sera, respectively. Viability of BPItreated bacteria was $<5 \%$ of untreated $E$. coli. 


\section{Whole susp. PMN pellet Supernatant}

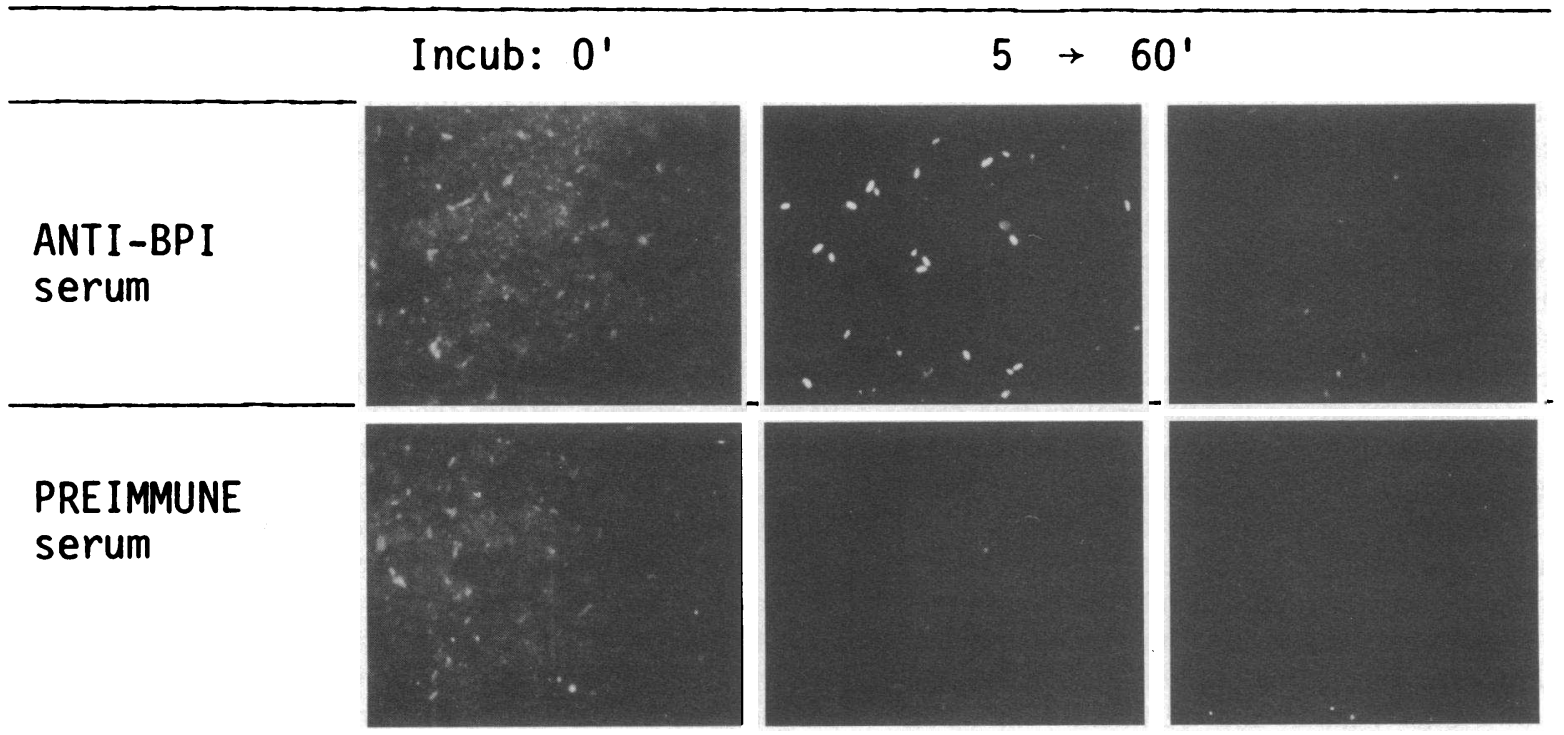

Figure 3. Immunofluorescent staining of $E$. coli $\mathrm{S} 15$ incubated with intact PMN. Indirect immunofluorescent staining of whole suspensions (susp.) of PMN and E. coli (mixed at $4^{\circ} \mathrm{C}$; left), resuspended PMN pellets (center), and extra-PMN supernatants (right) were carried out as described in Methods after sonication of cells to disperse

might reflect the release by $\mathrm{PMN}$ of weak $\mathrm{O}_{2}$-independent bactericidal activity evident only when small numbers of uningested $E$. coli remain.

\section{Discussion}

Extracellular cytotoxicity of PMN has been demonstrated toward a wide variety of cells including both large prokaryotes and eukaryotes (3). Extracellular killing of bacteria has also

Table III. Effect of Heat-treated and C6-depleted

Serum on Uptake and Killing of E. coli S15 by Human PMN in Room Air and Nitrogen

\begin{tabular}{|c|c|c|c|c|}
\hline Serum & Effect on $E$. coli & & $\begin{array}{l}\text { Room } \\
\text { air }\end{array}$ & Nitrogen \\
\hline & Uptake (\%) & & $57 \pm 2.2$ & $51 \pm 2.4$ \\
\hline \multirow[t]{4}{*}{ Heat-treated } & Viability (\%) in: & PMN pellet & $0.2 \pm 0.2$ & $7.4 \pm 3.3$ \\
\hline & & Supernatant & $22 \pm 7.1$ & $102 \pm 14$ \\
\hline & & $\begin{array}{l}\text { Whole } \\
\text { suspension }\end{array}$ & $9.4 \pm 2.9$ & $54 \pm 7.6$ \\
\hline & Uptake (\%) & & $78 \pm 1.3$ & $79 \pm 2.4$ \\
\hline \multirow[t]{3}{*}{ C6-depleted } & Viability (\%) in: & PMN pellet & $0.3 \pm 0.3$ & $1.8 \pm 0.7$ \\
\hline & & Supernatant & $20 \pm 8.7$ & $48 \pm 11$ \\
\hline & & $\begin{array}{l}\text { Whole } \\
\text { suspension }\end{array}$ & $5.7 \pm 2.3$ & $13 \pm 5.5$ \\
\hline
\end{tabular}

$E$. coli were incubated in room air or $\mathrm{N}_{2}$ for $30 \mathrm{~min}$ at $37^{\circ} \mathrm{C}$ in the standard incubation mixture containing $10 \%$ heat-treated or C6-depleted serum $\pm P M N$. Bacterial uptake and viability were measured as described under Methods and in the legends to Fig. 1 and Table II. The results shown represent the mean \pm SEM of five independent determinations. The viability of $E$. coli treated with $10 \%$ C6-depleted serum $(-\mathrm{PMN})$ was $98.2 \pm 7.3 \%(n=6)$ of bacteria incubated alone. the bacteria. Bacteria shown in upper and lower panels were treated with rabbit anti-BPI and preimmune sera, respectively. The pattern of staining of PMN-associated and of extracellular $E$. coli after 5, 15 (shown), 30, or $60 \mathrm{~min}$ incubation of $E$. coli with intact PMN was similar.

been shown, but only under artificial conditions, e.g., by adding cytochalasin D to block phagocytosis (20) or phorbol myristate acetate to stimulate oxidative metabolism and degranulation by PMN incubated with nonopsonized (noningested) bacteria (21).

This study demonstrates substantial extracellular killing of E. coli by phagocytizing human PMN, using opsonindeficient heat-treated serum to permit only partial uptake of bacteria. Although ingested $E$. coli are killed more rapidly, nearly equal numbers of dead bacteria are located within and outside the PMN when killing is maximal. The gradual reduction in viability of extracellular $E$. coli could conceivably be explained by slow uptake of viable bacteria concomitant with extrusion of dead $E$. coli. However, two findings strongly argue against this possibility. First, the number and fraction of PMNassociated $E$. coli killed under room air and $\mathrm{N}_{2}$ is almost the same, yet appreciable numbers of dead extracellular bacteria are recovered only from aerobic cell suspensions. Second, the granule protein BPI rapidly attached to ingested $E$. coli but is not detected on extracellular bacteria. It thus appears that $E$. coli recovered in the extracellular medium were never exposed to the intravacuolar environment of the PMN and, hence, were killed outside the PMN during incubation in room air.

The defect in extracellular killing exhibited by both $\mathrm{O}_{2}$ depleted normal PMN and CGD leukocytes indicates that oxidative mechanisms play an essential role in extracellular killing of $E$. coli $\mathrm{S} 15$ by human PMN. Extracellular killing is not seen in the absence of serum, presumably because the oxidative metabolism of the PMN is not adequately stimulated under these conditions. Which, of the many potentially cytotoxic $\mathrm{O}_{2}$ metabolites generated during the respiratory burst, is (are) primarily responsible for extracellular killing of $E$. coli by the human PMN is still uncertain. Passo and Weiss (21) 
have shown that oxidative killing of extracellular $E$. coli by phorbol myristate acetate-stimulated PMN is mediated principally by the myeloperoxidase- $\mathrm{H}_{2} \mathrm{O}_{2}-\mathrm{Cl}^{-}$system, and we find, in preliminary experiments, that azide and cyanide, inhibitors of myeloperoxidase, reduce killing of $E$. coli by PMN in room air to roughly the same levels observed under $\mathrm{N}_{2}$. In both studies, the rate of extracellular killing is slow (relative to intracellular killing), possibly reflecting the action of longlived, slowly reactive oxidants such as hydrophilic $N$-chloramines that accumulate in the extracellular medium (21-24) and can be bactericidal $(22,23)$. However, in agreement with Passo and Weiss, we do not find evidence of bactericidal activity in the supernatant of suspensions of PMN and $E$. coli (tested toward freshly added $E$. coli) suggesting that slow killing may reflect relatively slow accumulation of short-lived oxidants on the bacterial surface (21).

Although toxic $\mathrm{O}_{2}$ metabolites may also contribute to killing of PMN-associated $E$. coli, the virtually normal killing of these bacteria by $\mathrm{O}_{2}$-depleted normal PMN and by CGD leukocytes indicates that $\mathrm{O}_{2}$-independent mechanisms alone are sufficient to kill ingested $E$. coli. The slight increase in the number of viable $E$. coli recovered in the PMN pellet after incubation under $\mathrm{N}_{2}$ may be due at least in part to trapping of a small fraction (10\%) of live extracellular bacteria. The fact that increased bacterial ingestion (replacing heat-treated serum with C6-depleted serum) results in a corresponding reduction in bacterial survival under $\mathrm{N}_{2}$ supports this view and underscores the effectiveness of $\mathrm{O}_{2}$-independent intracellular killing of this strain of $E$. coli. Oxygen-independent killing of several strains of $E$. coli, $S$. typhimurium, and certain other species of gram-negative bacteria by rabbit and human PMN has previously been shown (12, 25-27). Both species of PMN possess multiple nonoxidative bactericidal systems (2, 28). In both rabbit and human $P M N$, the principal $\mathrm{O}_{2}$ independent bactericidal agent toward these gram-negative bacteria appears to be BPI, judging from the potency of BPI (in cell-free PMN fractions) and the similarity of the lesions initially inflicted by isolated BPI and by intact PMN $(10,12$, 29). The demonstration in this study that BPI rapidly binds to ingested $E$. coli satisfies a primary requisite for its action in the intact neutrophil $(17,18)$.

The absence of detectable BPI on noningested bacteria may explain the $\mathrm{O}_{2}$ dependence of extracellular killing of $E$. coli. This compartmentalization of $\mathrm{O}_{2}$-independent killing and the use of opsonin-deficient conditions have made this a particularly favorable setting for the demonstration of concomitant intra- and extracellular killing as well as of a previously unrecognized defect in extracellular killing by CGD leukocytes. Although heat-treated serum is a laboratory artifact, many situations occur in vivo in which (heat-labile) opsonins are deficient (19). The ability of PMN to generate toxic $\mathrm{O}_{2}$ metabolites against extracellular microorganisms provides an effective ("back-up") bactericidal mechanism which may be important under conditions when intracellular sequestration of bacteria is incomplete.

\section{Acknowledgments}

We are indebted to Dr. Henry W. Murray, Division of International Medicine, Cornell University Medical College, New York for making available the blood of both a patient with CGD and of a normal individual.

This work was supported by grant AM-05472 from the U. S. Public Health Service.

\section{References}

1. Root, R. K., and M. S. Cohen. 1981. The microbicidal mechanisms of human neutrophils and eosinophils. Rev. Infect. Dis. 3:565598.

2. Elsbach, P., and J. Weiss. 1983. A reevaluation of the roles of the $\mathrm{O}_{2}$-dependent and $\mathrm{O}_{2}$-independent microbicidal systems of phagocytes. Rev. Infect. Dis. 5:843-853.

3. Clark, R. A. 1983. Extracellular effects of the myeloperoxidasehydrogen peroxide-halide system. Adv. Inflammation Res. 5:107-146.

4. Densen, P., and G. L. Mandell. 1978. Gonococcal interactions with polymorphonuclear neutrophils. Importance of the phagosome for bactericidal activity. J. Clin. Invest. 62:1161-1171.

5. Murray, H. W., and D. M. Cartelli. 1983. Killing of intracellular Leishmania donovani by human mononuclear phagocytes. Evidence for oxygen-dependent and -independent Leishmanicidal activity. $J$. Clin. Invest. 72:32-44.

6. Böyum, A. 1968. Isolation of mononuclear cells and granulocytes from human blood. Scand. J. Clin. Lab. Invest. 97(Suppl.):77-89.

7. Simon, E. J., and D. van Praag. 1964. Inhibition of RNA synthesis in Escherichia coli by levorphanol. Proc. Natl. Acad. Sci. USA. 51:877-883.

8. Bradford, M. 1976. A rapid sensitive method for the quantitation of microgram quantities of protein utilizing the principle of proteindye binding. Anal. Biochem. 72:248-254.

9. Ouchterlony, O. 1949. Antigen-antibody reactions in gels. Acta Pathol. Microbiol. Scand. 26:507-515.

10. Weiss, J., P. Elsbach, I. Olsson, and H. Odeberg. 1978. Purification and partial characterization of a potent bactericidal and membrane-active protein from granules of human polymorphonuclear leukocytes. J. Biol. Chem. 253:2664-2672.

11. Victor, M., J. Weiss, and P. Elsbach. 1981. Heparin inhibits phagocytosis by polymorphonuclear leukocytes. Infect. Immun. 32: 295-299.

12. Weiss, J., M. Victor, O. Stendahl, and P. Elsbach. 1982. Killing of gram-negative bacteria by polymorphonuclear leukocytes. Role of an $\mathrm{O}_{2}$-independent system. J. Clin. Invest. 69:959-970.

13. Rausch, P. G., K. B. Pryzwansky, and J. K. Spitznagel. 1978. Immunocytochemical identification of azurophilic and specific granule markers in the giant granules of Chediak-Higashi neutrophils. N. Eng. J. Med. 298:693-698.

14. Weiss, J., R. C. Franson, S. Beckerdite, K. Schmeidler, and P. Elsbach. 1975. Partial characterization and purification of a rabbit granulocyte factor that increases permeability of Escherichia coli. $J$. Clin. Invest. 55:33-42.

15. Elsbach, P., P. Pettis, S. Beckerdite, and R. Franson. 1973. Effects of phagocytosis by rabbit granulocytes on macromolecular synthesis and degradation in different species of bacteria. J. Bacteriol. 115:490-497.

16. Seger, R. 1984. Inborn errors of oxygen-dependent microbial killing by neutrophils. Adv. Intern. Med. 51:29-116.

17. Weiss, J., S. Beckerdite-Quagliata, and P. Elsbach. 1980. Resistance of gram-negative bacteria to purified leukocyte proteins. Relation to binding and bacterial lipopolysaccharide structure. J. Clin. Invest. 65:619-628.

18. Weiss, J., M. Victor, and P. Elsbach. 1983. Role of charge and hydrophobic interactions in the action of the bactericidal/permeabilityincreasing protein of neutrophils on gram-negative bacteria. J. Clin. Invest. 71:540-549.

19. Root, R. K., and J. L. Ryan. 1985. Humoral immunity and complement. In Principles and Practice of Infectious Disease. G. L. 
Mandell, R. G. Douglass, and J. E. Bennett, editors. John Wiley \& Sons, Inc., New York. 31-57.

20. Okamura, N., S. Ishibashi, and T. Takano. 1979. Evidence for bactericidal activity of polymorphonuclear leukocytes without phagocytosis. J. Biochem. 86:469-475.

21. Passo, S. A., and S. J. Weiss. 1984. Oxidative mechanisms utilized by human neutrophils to destroy Escherichia coli. Blood. 63: 1361-1368.

22. Thomas, E. L. 1979. Myeloperoxidase, hydrogen peroxide, chloride antimicrobial system: nitrogen-chlorine derivatives of bacterial components in bactericidal action against Escherichia coli. Infect. Immun. 23:522-531.

23. Thomas, E. L. 1979. Myeloperoxidase-hydrogen peroxidechloride antimicrobial system: effect of exogenous amines on antibacterial action against Escherichia coli. Infect. Immun. 25:110-119.

24. Weiss, S. J., M. B. Lampert, and S. T. Test. 1983. Characterization and bioactivity of a novel class of long-lived oxidants generated by human neutrophils. Science (Wash. DC). 222:625-627.
25. Mandell, G. L. 1974. Bactericidal activity of aerobic and anaerobic polymorphonuclear neutrophils. Infect. Immun. 9:337-341.

26. Okamura, N., and J. K. Spitznagel. 1982. Outer membrane mutants of Salmonella typhimurium have lipopolysaccharide-dependent resistance to the bactericidal activity of anaerobic human neutrophils. Infect. Immun. 36:1087-1095.

27. Rest, R. F., M. H. Cooney, and J. K. Spitznagel. 1977. Susceptibility of lipopolysaccharide mutants to the bactericidal action of human neutrophil lysosomal fractions. Infect. Immun. 16:145-151.

28. Selsted, M. E., D. Szklarek, and R. I. Lehrer. 1984. Purification and antibacterial activity of antimicrobial peptides of rabbit granulocytes. Infect. Immun. 45:150-154.

29. Elsbach, P., J. Weiss, R. C. Franson, S. Beckerdite-Quagliata, A. Schneider, and L. Harris. 1979. Separation and purification of a potent bactericidal/permeability-increasing protein and a closely associated phospholipase $A_{2}$ from rabbit polymorphonuclear leukocytes. Observations on their relationship. J. Biol. Chem. 254:11000-11009. 